\title{
Combined Method of Coal Mining in the Opening of Shallow Layers as a Direction of Innovative Development of Geotechnology
}

\author{
Tatiana Tyuleneva $^{{ }^{*}}$, Roman Shishkov ${ }^{2}$, Elena Kucherova $^{1}$, and Marat Moldazhanov ${ }^{3}$ \\ ${ }^{1}$ T.F. Gorbachev Kuzbass State Technical University, Department of Management Accounting and \\ Analysis, 650000 Kemerovo, 28 Vesennya st., Russian Federation \\ ${ }^{2}$ Mining Institute of The Federal Research Center of Coal and Coal-Chemistry of Siberian Branch of \\ the Russian Academy of Sciences, 650000 Kemerovo, 18 Sovyetsky av., Russian Federation \\ ${ }^{3}$ Kazakh Humanitarian-Law Innovative University, Department of Finance and Accounting, 11 \\ Mangilik El st., Semey, East Kazakhstan region, 071400, Republic of Kazakhstan
}

\begin{abstract}
In recent years, there has been a decline in the efficiency of coal mining by traditional methods. On the one hand, the volume of coal outside the contour of the cut, which is economically impractical for openpit mining, is increasing. On the other hand, when using underground geotechnology, the cost of production exceeds the cost of performing mining operations using open geotechnology, this is due to differences in the factors of operation of the open pit and the mine. This circumstance determines the use of open-underground technology for mining coal reserves outside the contour of the open pit as an actual and promising direction. This article describes a methodological approach based on the use of technological schemes for the preparation and treatment of reserves of powerful shallow coal seams, the justification of the parameters of combined geotechnology with a coordinated and balanced development of open and open-underground mining operations with the distribution of reserves for open and open-underground mining of coal reserves beyond the limit contour of the open pit, the preparation of excavation sites directly from its workings and the coordination of production capacity and the speed of their development. Its application will increase the production capacity of the coal mining complex without additional environmental burden and will provide an increased return on investment.
\end{abstract}

\section{Introduction}

To date, coal mining enterprises with an open-pit mining method are experiencing a decrease in the volume of minerals suitable for extraction by traditional methods. As the research results show, the volume of coal remaining outside the contour of the cut and economically impractical for open-pit mining is increasing. When using underground geotechnology of coal mining, the costs of performing these works exceed the costs of mining using open geotechnology, this is due to differences in the factors of operation of

*Corresponding author: kta.bua@kuzstu.ru 
the section and the mine, the main of which include the high cost of opening and preparing the mine fields, transportation, ventilation and drainage. In connection with the above, the use of open-underground technology for mining coal reserves outside the contour of the section is a promising direction [1-3]. The problem of improving the open-pit mining method in the mining region, which is Kuzbass, is also consistent with the provisions of the energy strategy until 2035, and therefore is very relevant.

\section{Theory of Experimental Research}

In the conditions of the retiring capacities of the existing coal mines, the transition to deep horizons of work, it seems promising to work out coal reserves beyond the contour of the section using underground geotechnology. Scientific research [4-8] describes methods for substantiating technological solutions and parameters of underground and combined development of coal and ore deposits, increasing the production capacity of mining enterprises, their technical re-equipment and production with a full technological cycle of integrated development and preservation of the subsurface. The mining system is interpreted as a complex of technological systems of mining and production facilities associated with them in connection with the developed subsurface areas; their classification, used in the design of mining operations, makes it possible to choose a rational method of field development, taking into account mining and geological conditions. The results of the research confirmed that the combination of open-pit and underground coal mining technologies within the overall infrastructure will ensure a longer life of the coal mining enterprise and increase the degree of completeness of the field development. The main disadvantages of the above-mentioned open-underground methods are the insufficient intensity of the development of the coal deposit, due to the gradual transition from open to open-underground and underground mining, the complex structure of the «mine - block» system used in underground mining, which must be reoriented to open-underground technology, a long period of land reclamation, the need for consistent laying of trenches, which increases the period of development of the field, a large number of capital mining operations.

The use of combined methods of field development is traditionally accompanied by additional difficulties in the implementation of cleaning operations at the mine, as well as coal excavation work at the mine. These include a decrease in the strength and stability of the sides of the section due to the presence of underground mine workings, an increase in coal losses due to a large number of workings simultaneously carried out in the quarry massif, special, increased, industrial safety and labor protection requirements due to the use of heavy equipment by the section over the emptied underground mine workings. Of course, the combined development has a number of advantages: it reduces the duration of construction of structures for the implementation of underground or open-pit technologies, and increases the intensity of mining areas of the field, and reduces transportation costs, in addition, the development of reserves remaining in the increasing volume of the coal mine pillar, makes it possible to increase the completeness of the extraction of reserves from the subsurface areas and at the same time increase the life of the coal mining enterprise. To increase the efficiency of the open-pit mining methods implemented, it is necessary to ensure a balance and maximize the production capacity of the mine and the section, as well as the uniformity of the development of mining operations during the implementation of each of them. Only under such conditions, some works will not become an obstacle to the implementation of subsequent ones, and the subsequent ones, in turn, will not reduce the load due to the need to wait for third-party works to perform their own. Thus, in order to solve the problem of optimizing the development of coal mining, it seems appropriate to 
switch to a balanced application of combined field development technologies, which involve the use of the developed section space as the main opening development.

\section{Results and Discussion}

The study of the advantages and disadvantages of using underground and open-pit coal mining technologies made it possible to conclude that their integrated application, taking into account the noted advantages, can serve as a basis for the development of a combined method of field development. Taking into account the accumulated domestic and foreign experience of the open-underground system for the development of coal deposits allows us to obtain the following effects [9-14]: combine underground and open-pit mining operations within the mining system «cut - mine site»; to balance the duration of mining and the speed of mining operations in open and underground mining; to ensure the efficiency of coal mining at modular mine sites; to combine a significant part of the components of the production infrastructure: power lines, substations, transport routes, etc.; to increase the life of the mining enterprise.

Combined geotechnology involves a more detailed study of geomechanical processes due to the interdependence of open-pit and underground mining. The factors that determine the quantitative values of the geomechanical parameters of open-underground geotechnology applied to the formation of coal seams are shown in the Fig. 1.

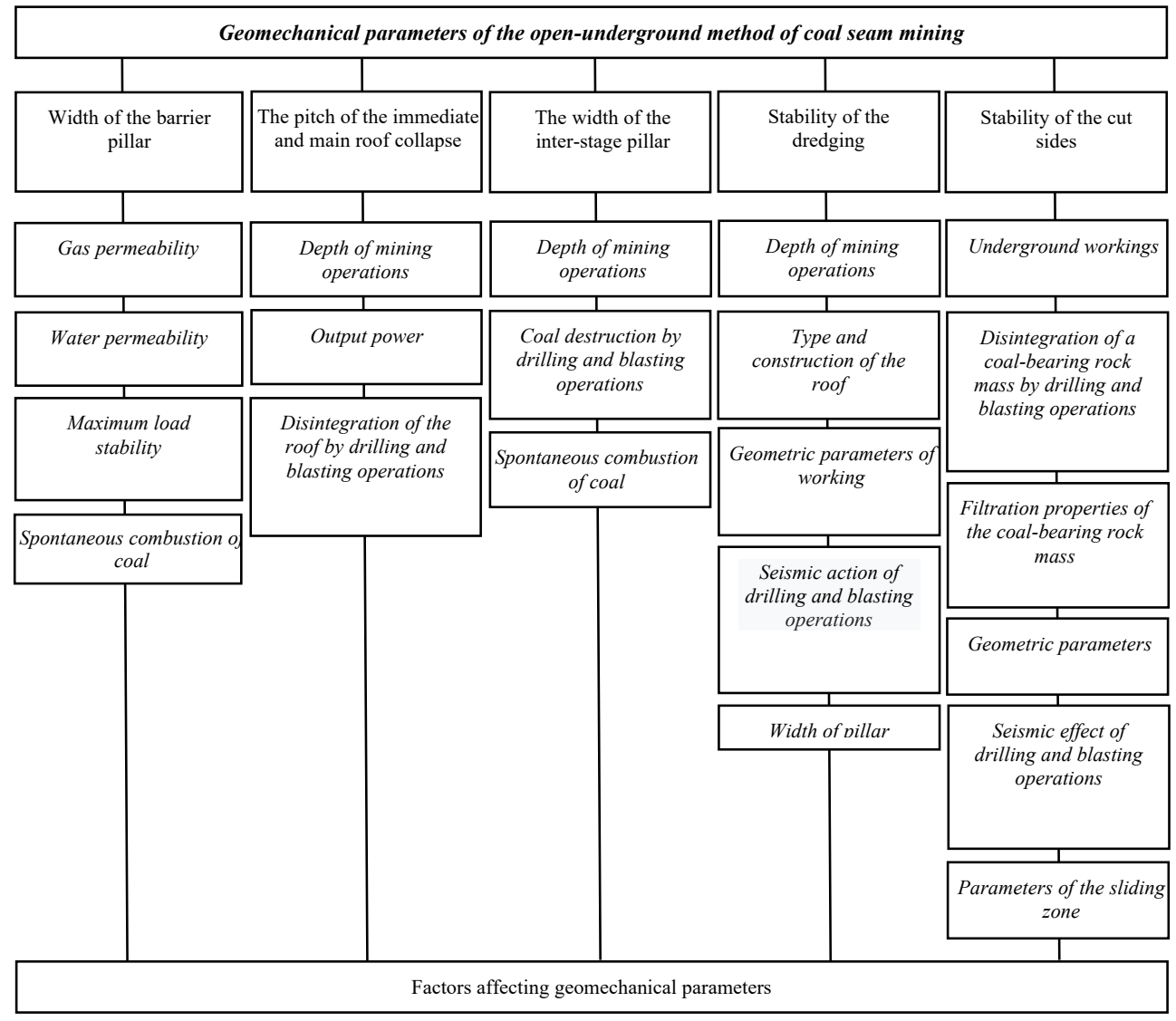

Fig. 1. Factors influencing the geomechanical characteristics of open-underground coal seam mining technology [15] 
At the same time, the efficiency of the transition to a combined open-underground geotechnology is provided by the existing production infrastructure, the possibility of coal transportation, the use of coal-cutting equipment, the possibility of internal dump formation with a boundary overburden coefficient. A feature of the geomechanical processes of the combined method of developing a coal deposit is the need to take into account the joint influence of open and underground work on the stress-strain state of the rock mass. The combined geotechnology of the work should exclude the impact of the treatment excavation of the section on underground mining operations, and the target left between the results of open-pit and underground mining operations should not be in the zone of influence of openpit mining on the underground excavation by mine pillars. The main geomechanical parameters of open-underground geotechnology are the slope angles of the slopes, the size of the remaining stable pillars, as well as the length, size and spatial location of the mine workings. The loads acting on pillars for various purposes depend on such geological and mining factors as the size of the excavation section of the section, the depth of its development, the physical and mechanical characteristics of the host rocks, etc. In the mine areas, pillars have a number of additional values, namely, more efficient ventilation of the excavation pillars, water and gas disposal during the development of lavas on the uprising. The width of the remaining guard posts located between two parallel preparatory workings on the side of the planned developed area should not be less than the width of the reference rock stress zone.

The use of combined methods of field development is traditionally accompanied by additional difficulties in the implementation of cleaning operations at the mine, as well as coal excavation work at the mine. These include a decrease in the strength and stability of the sides of the section due to the presence of underground mine workings, an increase in coal losses due to a large number of workings simultaneously carried out in the quarry mass, special, increased, industrial safety and labor protection requirements due to the use of heavy equipment by the section over the emptied underground mine workings. Of course, the combined development has a number of advantages: it reduces the duration of construction of structures for the implementation of underground or open-pit technologies, and increases the intensity of mining areas of the field, and reduces transportation costs, in addition, the development of reserves remaining in the increasing volume of pillar coal mines, makes it possible to increase the completeness of the extraction of reserves from the subsurface areas and at the same time increase the life of the coal mining enterprise. To increase the efficiency of the open-pit mining methods implemented, it is necessary to ensure a balance and maximize the production capacity of the mine and the section, as well as the uniformity of the development of mining operations during the implementation of each of them. Only under such conditions, some works will not become an obstacle to the implementation of subsequent ones, and the subsequent ones, in turn, will not reduce the load due to the need to wait for third-party works to perform their own. Thus, in order to solve the problem of optimizing the development of coal mining, it seems appropriate to switch to a balanced application of combined field development technologies, which involve the use of the developed section space as the main opening development.

Due to the fact that the opening mining and capital workings in the modular mine sections were not used, there was a four-fold saving in the cost of opening and preparation compared to the classical method. The positive economic effect of using the proposed method is expressed in a reduction in production costs (the option after the implementation of design solutions compared to the basic option, Table 1). In addition, when using this method, due to a reduction in the time spent on construction, an increase in the length of the excavation pillars and the conduct of concentrated preparatory work on site workings, underground mining of open-pit mine sites was reduced by 5 years when reaching production capacity, almost 2 times greater. 
Table 1. Comparison of key indicators before and after the implementation of project solutions [15]

\begin{tabular}{|c|c|c|c|c|}
\hline \multirow[t]{2}{*}{ Activity } & \multirow{2}{*}{$\begin{array}{c}\text { After the } \\
\text { implementation } \\
\text { of design } \\
\text { solutions }\end{array}$} & \multirow{2}{*}{$\begin{array}{c}\text { Before } \\
\text { implementing } \\
\text { design } \\
\text { solutions }\end{array}$} & \multicolumn{2}{|c|}{ Deviation } \\
\hline & & & $\begin{array}{c}\text { in } \\
\text { amount }\end{array}$ & $\begin{array}{c}\text { in } \\
\text { percentage }\end{array}$ \\
\hline $\begin{array}{l}\text { Overburden and preparatory work, } \\
\text { mln rubles }\end{array}$ & 356.6 & 1517.4 & -1160.8 & -76.5 \\
\hline $\begin{array}{l}\text { Maintenance of mine workings, } \\
\text { mln rubles }\end{array}$ & 17.8 & 75.9 & -58.1 & -76.55 \\
\hline Electricity costs, $\mathrm{mln}$ rubles & 77.7 & 194.5 & -116.8 & -60.05 \\
\hline Production capacity, mln tons & 8 & 5 & +3 & +60 \\
\hline Calculation horizon, years & 5.6 & 11 & -5.4 & -49.09 \\
\hline
\end{tabular}

\section{Conclusion}

A method based on the use of rational technological schemes for the preparation and treatment of reserves of powerful shallow coal seams, justification of the parameters of combined geotechnology with a coordinated and balanced development of open and openunderground mining operations, characterized by a rational distribution of reserves for open and open-underground mining of coal reserves beyond the limit contour of the cut with the preparation of excavation sites directly from its workings, while coordinating the production capacity and development rates of open and open-underground work, ensuring the specified terms of timely repayment of underground workings for the safe internal dumping of overburden in the developed space of the section.

The method allows the use of reserves with increased environmental safety due to the use of less land capacity, since a balanced development will allow to work out reserves at a time, without leaving the coal seam behind the contour of the working side of the section. As a result, the opportunities for open-pit mining in the combined development system are expanded by eliminating the need for a single trench, as a result of the balance of production capacities of open-pit and underground mining with the calculation of the division of total reserves in the boundary of the mining allotment for open-pit mining. As a result, the coal mine will be able to use its resources more efficiently, together with rational underground mining. When using the described method, the production capacity of the coal mining complex increases without exaggerating the load on the environment. Using the adjacent infrastructure of the section from the point of view of underground mining, an increased return on investment is predicted, due to the exclusion of capital workings, which occupy a significant share in the amount of the component of the cost of underground mining (air supply, drainage, maintenance, capital investment for conducting).

\section{References}

1. V. Mikhailov, V. Karasev and G. Mikhailov, E3S Web of Conf., 41, 02015 (2018)

2. T. Tyuleneva and M. Moldazhanov, E3S Web of Conf., 174, 04061 (2020)

3. T. Tyuleneva, Proceedings of the 9th China-Russia Symposium "Coal in the 21st Century: Mining, Intelligent Equipment and Environment Protection", 352 (2018)

4. L. V. Kuznetsova and B. A. Anfyorov, IOP Conf. Series: Earth and Environmental Science, 012003 (2019)

5. D. Kaplunova, D. Bekbergenov and G. Djangulova, E3S Web of Conf., 01015 (2018) 
6. V. A. Fedorin, V. Shakhmatov, B.A. Anferov and L.V. Kuznetsova, IOP Conf. Series: Earth and Environmental Science, 012015 (2018)

7. V. A. Fedorin, V. Ya. Shakhmatov and A. Yu. Mikhailov, Vestn Nauch. Tsentra VostNII po Prom. Ekol. Bezop., 1, 32 (2018)

8. I. V. Sokolov, A. A. Smirnov and Y. G. Antipin, Journal of Mining Science, 54, 226 (2018)

9. T. V. Kiseleva, V. G. Mikhailov and G. S. Mikhailov, IOP Conf. Series: Earth and Env. Sci., 84, 012044 (2017)

10. T. Tyuleneva, E3S Web of Conf., 174, 04019 (2020)

11. L. Krupnik, Y. Shaposhnik, A. Konurin, S. Shaposhnik and D. Shokarev, Mining of Mineral Deposits, 12, 4, 108 (2018)

12. A. M. Mazhitov, S. A. Korneev, I. A. Pytalev and T. S. Kravchuk, IOP Conf. Series: Earth and Environmental Science, 052017 (2017)

13. A. N. Rakhmangulov, K. V. Burmistrov and N. A. Osintsev, Sustainability, 13, 3, $1101(2021)$

14. D. Kaplunov, M. Rylnikova, D. Radchenko, E3S Web of Conf., 04002 (2018)

15. R. I. Shishkov and V. A. Fedorin, E3S Web of Conf., 174, 02013 (2020) 